\title{
The Political and Cultural Meanings of the Hittite Empire Period Rock Monuments
}

\author{
By Turgut Yigit*
}

The rock monuments of the Hittites, sometimes with impressive descriptions, still continue to remind us of the 2 nd millennium B.C. in many parts of Anatolia.

As a result of the determination of parallelisms between the rock monuments, their location, depictions, inscriptions and the data obtained from them with cuneiform texts; it was observed that they have political and cultural connotations and suggest important ideas about historical geography. Similarly to other Ancient civilizations, religion is intensively observed in every field of human life in the Hittites and coeval societies. This case was undoubtedly reflected on the rock monuments, both the depictions and all the hieroglyph inscriptions were presented in this sense.

The rock monuments which can be confronted individually in different places of Anatolia, from West to East, are regarded as the sign representing and emphasizing the sovereignty of the Hittite Empire in some places and as the sign of existence of local principalities under the domination of this political force in others. In addition to the meaning mentioned above; the rock monuments which are located in the area from Kayseri to Cukurova and then towards North Syria are considered as the signs of the transportation route used at that period.

The Hittite kingdom was founded in the second half of the $17^{\text {th }}$ century B.C. Its capital was in Central Anatolia and it continued its sovereignty over a vast area for about 450 years. From its foundation the kingdom broadened its influence reaching to the west and southeast of Anatolia and even to Northern Syria and left a permanent influence in this vast area. However, the Hittite kingdom rapidly deteriorated from the beginning of the $12^{\text {th }}$ century B.C. and for various reasons it finally collapsed.

The Hittites spoke one of the oldest known languages which is considered to belong in the Indo-European language group. They continued their sovereignty by making different ethnic groups in Anatolia directly or indirectly subjected to the kingdom. We can learn about the Hittite's civilization thanks to thousands of documents written in cuneiform which exist today. Cuneiform was improved in the cultural atmosphere of Mesopotamia. For this reason, the Hittite culture was also predominantly influenced by the Mesopotamian culture. We always encounter cuneiform on clay tablets. However, hieroglyphs are encountered on big stones or monuments made on rock surfaces. This form of writing was used in the Hittite period and is a form of writing that is completely unique to Anatolia. Tablets written with cuneiform are encountered in ruins of Hittite cities and in archives which remain underground. On the other hand, Anatolian hieroglyphs on rock monuments, sometimes with

${ }^{*}$ Professor, Ankara University, Turkey. 
impressive descriptions, still continue to tell us about the 2nd millennium B.C. in many parts of Anatolia.

The Hittite Period Rock Monuments are composed of various depictions on rock walls or block stones in the Hittite Empire Period, short hieroglyph inscriptions together with these depictions or longer hieroglyph inscriptions on without depictions. Rock monuments around the Hittite culture were made in the Empire Period (1400-1190 B.C.) or the Late Hittite Period (1190-700 B.C.). The Late Hittite Period was the period of principalities which took place after the dissolution of the Hittite Empire being established partly on the lands of this empire and with the claim of being subsequent of this empire in a political and cultural sense, yet in fact being too far from this claim. The Rock Monuments of the Late Hittite Period differ from the Rock Monuments of the Hittite Empire Period, since they reflect the cultural and political atmosphere of this period.

Most of the monuments on the rock walls and on the big block stones are still in their original places. Those which are portable are under protection in museums.

We see that these monuments in different places of Anatolia are intense in Hattusa, the capital city of Hittite and Alacahöyük which is close to it and especially in the area of the south of Kizllirmak bend which is accepted as the central area of Hittites. It is no doubt that this situation is related with the political meaning of the rock monuments, which is one of the reasons of their construction.

As a result of the determination of parallelisms between the rock monuments, their locations, depictions, inscriptions and the data obtained from them with cuneiform texts; it was observed that they have political and cultural connotations and suggest important ideas about historical geography. Similarly with other ancient civilizations, religion is intensively observed in every field of human life in the Hittites and coeval societies. This case was undoubtedly reflected in rock monuments, both depictions and all the hieroglyph inscriptions were presented in this sense. While Yazılıkaya and Alacahöyük reliefs present the most distinctive examples of them, there are godlike figures or other depictions integrated with this perception on other reliefs. The reflection of the religious belief of the period through the rock monuments can be supported with parallelisms created with written texts.

When we examine the rock monuments from the Hittite Empire Period in general terms, we see that they are mostly located in Central Anatolia, extending to the south. These monuments of the Hittite Empire Period describe the political, economic and cultural situation of the time in relation to their location and to the descriptions and inscriptions on them. The rock monuments which can be confronted individually in different places of Anatolia from west to east are regarded as the sign representing and emphasizing the sovereignty of the Hittite Empire in some places and as the sign of existence of local principalities under the domination of this political force in others.

The main purpose of this study is to examine the monuments located on the route extending from the central area of the kingdom to Southeastern 
Anatolia and to Northern Syria (figure 1), which were considered to be the most important destinations of the kingdom.

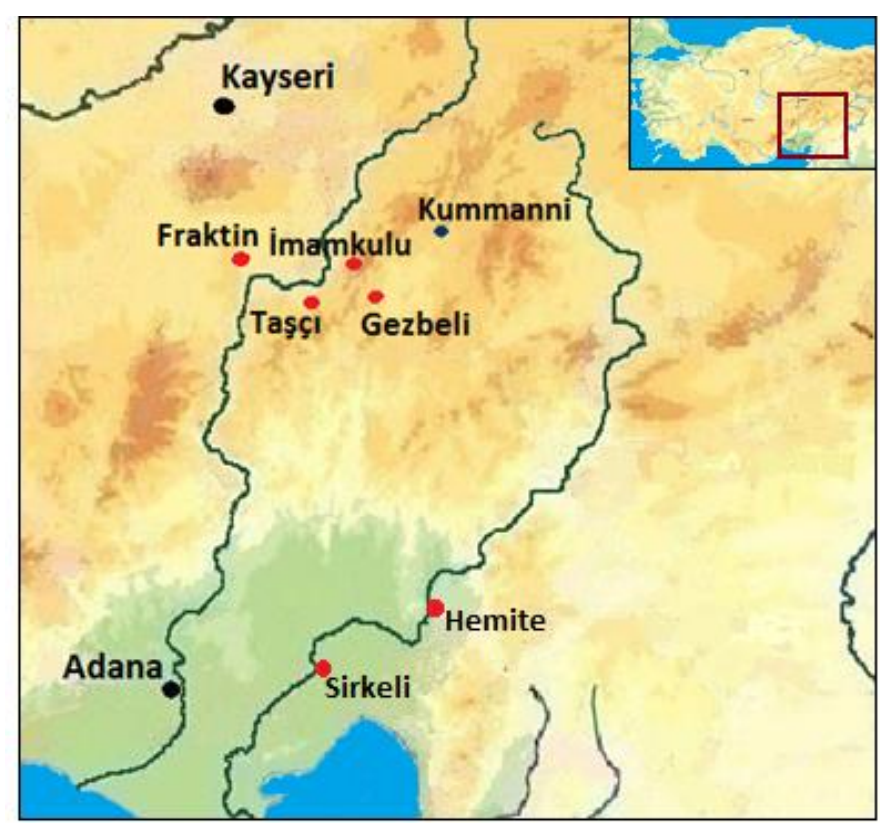

Figure 1. Hittite Rock Monuments on the route from Central Anatolia to Northern Syria

Source: Author

The Hittites founded a strong kingdom and then broadened the borders of this kingdom by means of areas which directly connected the center and the vassal kingdoms. They took military, political and economic precautions so that the kingdom could maintain its power in the areas it controlled. They followed the routes determined by natural obstacles to Southeastern Anatolia and Northern Syria in order to develop their relations in Anatolia and Northern Syria. The routes they followed are known from various sources, particularly the documents written in cuneiform and also from the rock monuments along the routes. These monuments reveal not only the routes and the relations they made but also the political and geographical status of the places in the Hittite Kingdom.

There is a road heading to Southeastern Anatolia and Northern Syria from Hattusa, the capital of the Hittites. The road passes first through Kayseri and then through Çukurova on the south, finally arriving in the Southeastern Anatolia and Northern Syria crossing the Nur Mountains.

The natural path which continues from the Develi district south of Mount Erciyes to the southeast; reaching Yukarı Ova and then descending to Çukurova by going beyond the mountain passes is marked with various rock monuments from the Hittite Empire Period. This was undoubtedly more than a marking the path; it was to remind us that a kingdom leaves its traces on the important transportation routes under its rule. The Fraktin monument (figure 2) which has figures and hieroglyph inscriptions on the rock wall is $1 \mathrm{~km}$ from the 
Zamant1 River southeast of the Develi dates back to the period where the Hittite Kingdom was at its strongest period and was under the greatest Hurrian influence. The monument describes king Hattusili III who lived in the $13^{\text {th }}$ century B.C. and his wife Puduhepe was the most important factor in the spread of Hurrian culture over the Hittite lands ${ }^{1}$. There are the Storm God and king Hattusili III in the first scene and main goddess and queen Puduhepa in the second scene of the rock panel. These scenes show the king and queen pouring libation to the top deities of the Hittites. There is a short hieroglyph inscription on the right side of the scene ${ }^{2}$, which was read as "daughter of the country Kizzuwatna, beloved of the gods"3. This monument is a symbol of power and sovereignty and is located near a challenging mountain pass and must have been located on the way used in the Hittite Period.

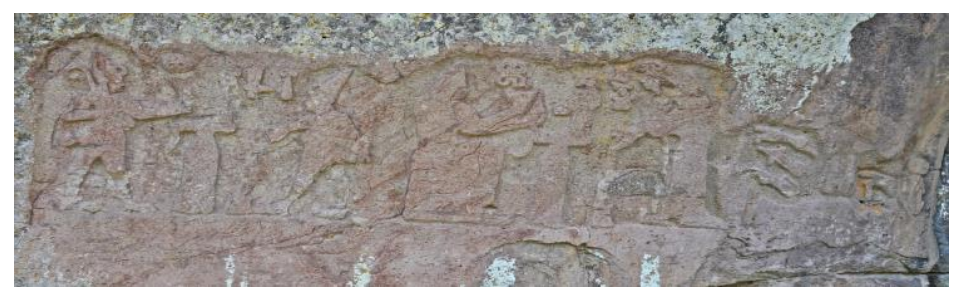

Figure 2. Fraktin Relief

Source: Author

When one goes further by following the Zamant1 River bed, hieroglyph inscriptions and descriptions engraved on rock surfaces known as Taşc1 A (figure 3) and B are encountered. The hieroglyph inscriptions have the name of the Hittite king Hattusili written on them, and there are the pictures of some senior officials on the worn out descriptions ${ }^{4}$. They depict the existence and power of the Hittite Kingdom to the people passing by.

1. R. L. Alexander, "Contributions to the interpretation of the Fraktın reliefs," (Acts of the 3rd International Congress of Hittitology, 1998), 15.

2. F.C. Woudhuizen, Luwian Hieroglyphic Monumental Rock and Stone Inscriptions from the Hittite Empire Period (Innsbruck: Institut für Sprachen und Literaturen der Universität Innsbruck, 2004), 65-71.

3. H. G. Güterbock "Die Hieroglypheninschrift von Fraktin" [The hieroglyphic inscription of Fraktin], (Festschrift Lubor Matouš, Herausgegeben von B. Hruška-G. Komoróczy, Budapest, 1978), 133.

4. E. P. Rossner Die hethitischen Felsreliefs in der Türkei. Ein archäologischer Führer [The Hittite rock reliefs in Turkey. An archaeological guide] (München : E. P. Rossner, 1988), 170; K. Kohlmeyer, "Felsbilder der hethitischen Großreichzeit" [Rock reliefs of Hittite Empire Period]. Acta Prehistorica et Archaeologica 15 (1983): 77, fig. 29-30; K. Kohlmeyer, "Anatolian Architectural Decorations, Statuary and Steale", in Civilizations of the Ancient Near East 3-4, ed. J. M. Sasson (New York: Scribner, 1995), 2653; F. Steinherr, "Zu den Felsinschriften Taşçı I und II" [The rock inscriptions Taşçı I and II], Istanbuler Mitteilungen 25, (1975): 315; K. Bittel, Die Hethiter. Die Kunst Anatoliens vom Ende des 3. bis zum Anfang des 1. Jahrtausends vor Christus [The Hittites. The art of Anatolia from the end of the 3rd millennium BC to the beginning of the 1st millennium BC], (München, 1976), 185; H. Ehringhaus, Götter, Herrscher, Inschriften. Die Felsreliefs der Hethitischen Grossreichszeit in der Türkei [Gods, Rulers, Inscriptions. The rock reliefs of the Hittite Empire Period in Turkey] (Mainz am Reihn: Verlag Phillip von Zabern in Wissenschaftliche Buchgesellschaft, 2005), 66; 


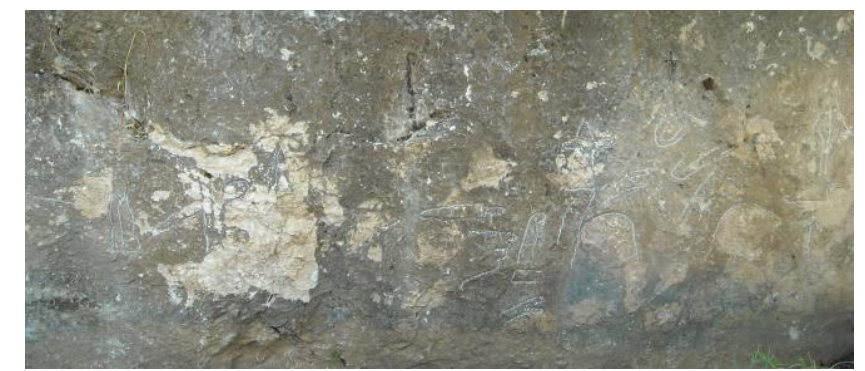

Figure 3. Taşcl A Inscription

Source: Author

After Taşc1 there is another rock monument located $18 \mathrm{~km}$ to the east. This is known as the İmamkulu Relief (figure 4) named after the village nearby. The relief was carved on the flattened rock surface. The scene shows a prince on the left and the Storm God in his chariot in the middle. Traces of paths which dated back to the Hittite period are not encountered in this region. However, depending on the land properties, the route that modern paths follow today particularly along the river must have been the same in the Hittite Period. This can be determined by the rock monuments. The land becomes rough starting from the İmamkulu Relief towards the high mountain pass. The path which is on the route to the most important political, military, economic and cultural targets of the Hittites reaches to the $1960 \mathrm{~m}$ high mountain pass in Gezbeli. On the point where the most challenging part of the mountain pass ends and where the path descends towards a valley in which the Hanyeri Rock Relief is located (figure 5). It is engraved on the rock on the way to where the modern highway passes. There is a prince, a bull standing on the mountain gods and two hieroglyph inscriptions. The name of the prince is read as Kuwalanamuwa. The other hieroglyph inscription also has a prince name. It reads as Tarhuntapiyami ${ }^{5}$. The descriptions involve details showing the power of the Hittite Kingdom and there is an inscription in hieroglyph. The name of a local prince is seen on this relief and it is inferred that the lands until the mountain pass are directly under the control of the Hittite king however, behind the pass is under the control of a local prince. However, this prince is subjected to the king of Hittite and it is one who preserves the interests of the king in this region. The interests include the ones within the framework of the military, political, economic relations provided by this mountain path. We can predict that mountains at the highest point of the pass that creates problems for transportation is a border between two political units.

J. D. Hawkins, Corpus of Hieroglyphic Luwian Inscriptions, Volume. I: Inscriptions of the Iron Ages (Berlin: de Gruyter, 2000), 39.

5. H. Ehringhaus, Götter, Herrscher, Inschriften. Die Felsreliefs der Hethitischen Grossreichszeit in der Türkei [Gods, Rulers, Inscriptions. The rock reliefs of the Hittite Empire Period in Turkey] (Mainz am Reihn: Verlag Phillip von Zabern in Wissenschaftliche Buchgesellschaft, 2005), 80. 
Figure 4. Imamkulu Relief

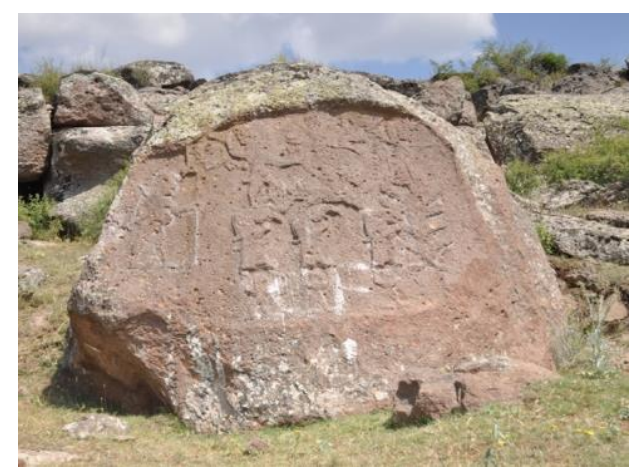

Source: Author

Figure 5. Hanyeri Relief

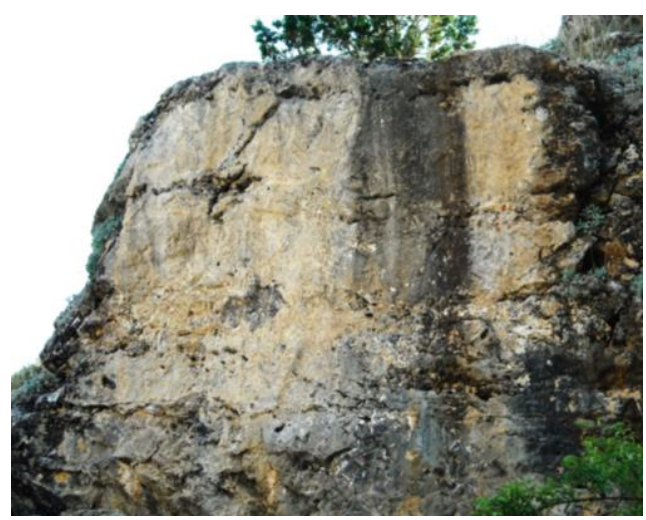

Source: Author

When we continue from the Hanyeri Rock Relief to the east, we reach the Shar Ruins where a cult city known as Kummanni in the Hittite Period is located $40 \mathrm{~km}$ after the route followed by the modern highway. The Hittite path which crosses such a challenging passage must have been absolutely designed to reach Kummanni ${ }^{6}$. This city was an important way point in the Hittite relations with Northern Syria. Kummanni also had an important intermediary role in transferring the Mesopotamian culture to the Hittites via the Hurrians. The path continued towards the southeast, crossed the rough land and then reached Northern Syria and the Amik Valley.

When the path crossing Gezbeli turns to the east and Kummanni, it also turns south and reaches the heart of Kizzuwatna, which was the most important political and economic asset of the 2 nd millennium B.C. as reflected in written texts of the Hittite Period.

There is a relief engraved on the rock surface near the Ceyhan River where we descend to the plain after passing the mountainous areas. This rock relief is called Hemite (figure 6) after the nearby village and it is similar to the Hanyeri

6. A. Ünal, "Adana'da Kizzuwatna Krallığı Taş Devrinden Hitit Devleti’nin Yıkılışına Kadar Adana ve Çukurova Tarihi" [Kizzuwatna Kingdom in Adana. History of Adana and Cukurova from the Stone Age to the fall of the Hittite Kingdom] in Efsaneden Tarihe, Tarihten Bugüne Adana Köprü Başı ed. E.Artun, M.S. Koz (Istanbul, 2000), 66. 
Relief. There is a male figure and a hieroglyph inscription behind the figure. The name of a local prince is seen in the hieroglyphs ${ }^{7}$. This monument marks where a small dynasty had recognized and accepted the Hittite rule. There is also another Hittite rock monument in Çukurova. The Sirkeli Relief (figure 7) located near the Ceyhan River but on the southwest according to the Hemite is the oldest Hittite relief. It includes an inscription where the name of the Hittite king, Muvatalli, who ruled in the beginning of the $13^{\text {th }}$ century B.C. can be read with a description of the King. The inscription reads as "Muwatalli, Great King, the Hero, (son of) Mursili, Great King, the Hero" 8 This region was undoubtedly interesting for the Hittite Kingdom, besides its rich agricultural production and other economic potential it was on the route to Northern Syria and Southeastern Anatolia. The paths which continued towards the east through two mountains pass and arrive in Northern Syria.

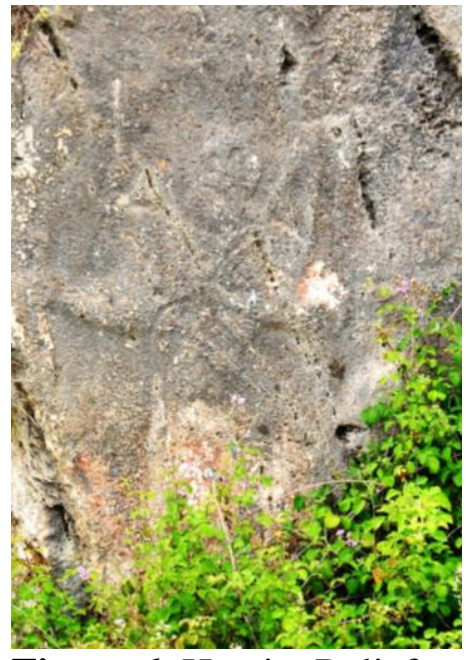

Figure 6. Hemite Relief Source: Author

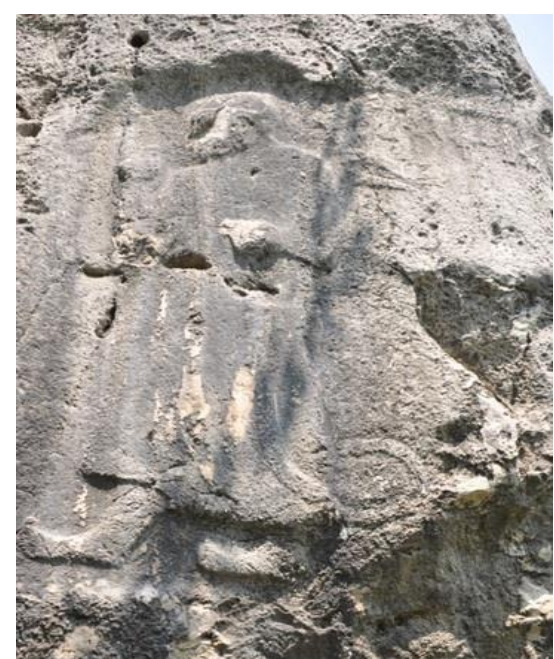

Figure 7. Sirkeli Relief

Source: Author

Since the foundation of the Hittite Kingdom in the $17^{\text {th }}$ century B.C. until its collapse (1190 B.C.), the main focus of the kingdom's foreign policy was Southeastern Anatolia and Northern Syria. The kingdom attached great importance to the control of these regions and ruled Northern Syria since the $14^{\text {th }}$ century B.C., which had political, economic and cultural reasons. The Hittites never stopped military incursions in Southeastern Anatolia and Northern Syria in order to reach their goals and maintain the control of the area. The Hittites during their military invasions used the route through the

7. H. Ehringhaus, Götter, Herrscher, Inschriften. Die Felsreliefs der Hethitischen Grossreichszeit in der Türkei [Gods, Rulers, Inscriptions. The rock reliefs of the Hittite Empire Period in Turkey] (Mainz am Reihn: Verlag Phillip von Zabern in Wissenschaftliche Buchgesellschaft, 2005), 108.

8. A. Unal and Girginer S., Kilikya-Çukurova: Ilk çağlardan Osmanlılar Dönemi'ne Kadar Kilikya'da Tarihi Coğrafya, Tarih Ve Arkeoloji [Cilicia-Cukurova: Historical Geography, History and Archaeology from the Early Ages until the Ottoman Period in Cilicia]. (1.basım. Istanbul: Homer Kitabevi, 2007), 150. 
rock monuments described above. It is necessary to mention that this route was not the only one and there were maybe more practical paths to Southeastern Anatolia and Northern Syria from Kayseri to Malatya and then to the Euphrates River Basin.

There were political units represented by different ethnic factors in Anatolia in the 2nd millennium B.C. In order to make its power felt and to benefit from the richness of areas under its control in order to continue its existence the Hittites collected regular taxes and war prizes. This situation resulted in inevitable military invasions. Southeastern Anatolia and Northern Syria attracted the attention of the great kingdoms in the nearby regions as the trade routes extending from Mesopotamia, Egypt, Iran, Anatolia and the trade cities on the Eastern Mediterranean coast were located in these areas. The Hittites were interested in this area for the same reasons. Before the foundation of the Hittite Kingdom, representatives of the Mesopotamia high-level civilizations travelled to Anatolia through the route which was determined with rock monuments after passing through Northern Syria for commercial purposes. From the $17^{\text {th }}$ century B.C., commercial relationships were maintained from Central Anatolia to Çukurova, Northern Syria and further places, all of which were in the same direction and under the Hittite control. However, this route was not only used for commerce it was also important for military purposes.

High-level civilizations which were born in Mesopotamia started to influence Anatolia earlier, but in the $2^{\text {nd }}$ millenium B.C this influence became stronger. The Hittites were not so far away from the influence of high-level civilizations which were developing nearby Anatolia and this is clearly seen in many fields such as language, religion, law, writing, literature and art. Northern Syria which was located in between these two geographical regions contributed to the cultural influence of Mesopotamia to a great extent. The Hurrians, whose presence can be observed in this region, had a very important role of intermediary in this interaction. They reinterpreted the elements of the Mesopotamian culture in their own culture and transferred them to the Hittites. The Hurrians, which were in Southeastern Anatolia and Northern Syria, extended their influence until Çukurova and then to the inner parts of Anatolia. The route of the rock monuments played an important role for the extension of the Mesopotamian culture, towards the inner parts of Anatolia; because this route is closely related to the regions where an intense Hurrian culture can be observed in Anatolia. The inscriptions on some rock monuments give evidence to support this cultural transfer.

The route which is determined via the rock monuments starting from the Hittite capital to Southeastern Anatolia and to Northern Syria was important for the Hittites in military, economic and cultural terms. 


\section{Bibliography}

Alexander, R. L. "Contributions to the interpretation of the Fraktın reliefs." In Acts of the 3rd International Congress of Hittitology, 1998: 15-20.

Bittel, K. Die Hethiter. Die Kunst Anatoliens vom Ende des 3. bis zum Anfang des 1. Jahrtausends vor Christus [The Hittites. The art of Anatolia from the end of the 3rd millennium BC to the beginning of the 1st millennium BC], München, 1976.

Güterbock, H. G. "Die Hieroglypheninschrift von Fraktin" [The hieroglyphic inscription of Fraktin], Festschrift Lubor Matouš, Herausgegeben von B. HruškaG. Komoróczy, Budapest, 1978: 127-136.

Ehringhaus, H. Götter, Herrscher, Inschriften. Die Felsreliefs der Hethitischen Grossreichszeit in der Türkei [Gods, Rulers, Inscriptions. The rock reliefs of the Hittite Empire Period in Turkey]. Mainz am Reihn: Verlag Phillip von Zabern in Wissenschaftliche Buchgesellschaft, 2005.

Hawkins, J.D. Corpus of Hieroglyphic Luwian Inscriptions, Volume. I: Inscriptions of the Iron Ages. Berlin: de Gruyter, 2000.

Kohlmeyer, K.. "Felsbilder der hethitischen Großreichzeit" [Rock reliefs of Hittite Empire Period]. Acta Prehistorica et Archaeologica 15 (1983): 7-153.

Kohlmeyer, K. "Anatolian Architectural Decorations, Statuary and Steale". In Civilizations of the Ancient Near East 3-4, edited by J. M. Sasson, 2639-2660. New York: Scribner, 1995.

Rossner, E.P.. Die hethitischen Felsreliefs in der Türkei. Ein archäologischer Führer [The Hittite rock reliefs in Turkey. An archaeological guide]. München: E. P. Rossner, 1988.

Steinherr, F. "Zu den Felsinschriften Taşçı I und II" [The rock inscriptions Taş̧̧ı I and II]. Istanbuler Mitteilungen 25 (1975): 313-317.

Ünal, A. "Adana'da Kizzuwatna Krallığı Taş Devrinden Hitit Devleti'nin Yıkılışına Kadar Adana ve Çukurova Tarihi" [Kizzuwatna Kingdom in Adana. History of Adana and Cukurova from the Stone Age to the fall of the Hittite Kingdom ]. In Efsaneden Tarihe, Tarihten Bugüne Adana Köprü Başı edited by E. Artun, M.S. Koz, Istanbul, 2000: 43-69.

Ünal, A. and K. Serdar Girginer. Kilikya-Çukurova: Ilk çağlardan Osmanlılar Dönemi'ne Kadar Kilikya'da Tarihi Coğrafya, Tarih Ve Arkeoloji : [CiliciaCukurova: Historical Geography, History and Archaeology from the Early Ages until the Ottoman Period in Cilicia]. 1.basım. Istanbul: Homer Kitabevi, 2007.

Woudhuizen, F.C. Luwian Hieroglyphic Monumental Rock and Stone Inscriptions from the Hittite Empire Period. Innsbruck: Institut für Sprachen und Literaturen der Universität Innsbruck, 2004. 
